\title{
Wealth Concentration in a Developing Economy: Paris and France, 1807-1994
}

\author{
By Thomas Piketty, Gilles Postel-Vinay, and Jean-Laurent Rosenthal**
}

\begin{abstract}
Using large samples of estate tax returns, we construct new series on wealth concentration in Paris and France from 1807 to 1994. Inequality increased until 1914 because industrial and financial estates grew dramatically. Then, adverse shocks, rather than a Kuznets-type process, led to a massive decline in inequality. The very high wealth concentration prior to 1914 benefited retired individuals living off capital income (rentiers) rather than entrepreneurs. The very rich were in their seventies and eighties, whereas they had been in their fifties a half century earlier and would be so again after World War II. Our results shed new light on ongoing debates about wealth inequality and growth. (JEL H20, J14, N20)
\end{abstract}

This article presents new series on wealth concentration in Paris and France from 1807 to 1994. It thus extends the series presented in Thomas Piketty $(2001,2003)$ by a full century and our new series are the first homogeneous series of wealth inequality to cover a span of time sufficient to fully evaluate Simon Kuznets's hypothesis (1955) about the rise and fall of inequality as economies develop. While other scholars have put together measures of wealth inequality over time, they have either

\footnotetext{
* Piketty: Paris-Jourdan Science Economiques (UMR CNRS-EHESS-ENS-ENPC), 48 boulevard Jourdan, 75014 Paris, France (e-mail: piketty@ens.fr); Postel-Vinay: Institut National de la Recherche Agronomique and Ecole des Hautes Etudes en Sciences Sociales, 48 boulevard Jourdan, 75014 Paris, France (e-mail: gpv@ens.fr); Rosenthal: Department of Economics, UCLA, Los Angeles, CA 90095 1477 (e-mail: rosenthal@econ.ucla.edu). We thank the Archives de Paris and the Direction Nationale d'Intervention Domaniales du Ministère des Finances for their assistance in data collection; the Guggenheim Foundation, the McArthur Foundation, the Collins Fund at UCLA, the Institut National de la Recherche Agronomique, and the Ecole des Hautes Etudes en Sciences Sociales for financial support; and Lara Marchi, Madeleine Roux, and Marie Carmen Smyrnelis for help in data collection. Special thanks to Alena Lapatniova and Maria Chichtchenkova for extraordinary research assistance. We also thank Anthony Atkinson, Peter Lindert, Emmanuel Saez, Kenneth Sokoloff, and the participants of the All-UC group in Economic History Group's conference on the New History of Inequality, for their comments. All our series are available online at http://www.ccpr.ucla.edu/Research/ProjectWebsites/ Rosenthal/Rosenthal.aspx. A longer version of the paper is available as a CEPR Discussion Paper (Piketty et al., 2004).
}

done so for much shorter periods or spliced together disparate sources. Our series were constructed by collecting the population of individual estate tax returns in the Paris archives for various years between 1807 and 1902, and linking them to previously published tabulations by size of estate for various years between 1902 and 1994.

Our general motivation for building such series is the study of the two-way interaction between development and distribution. More specifically, one of our primary goals is to better understand the decline in income and wealth inequality that occurred during the first half of the twentieth century in today's developed countries. Recent research on France suggests that this decline was for the most part an accidental phenomenon associated with the collapse of capital incomes, ${ }^{1}$ rather than a spontaneous, two-sector, Kuznets-type process. ${ }^{2}$ In particular, the only reason why top income shares

\footnotetext{
${ }^{1}$ See Piketty (2003). For similar series covering the United States, see Piketty and Emmanuel Saez (2003) and for the United Kingdom, see Anthony B. Atkinson (2005). Similar top income series covering most of the twentieth century have now been constructed for about 20 countries (see Atkinson and Piketty, forthcoming).

${ }^{2}$ According to Kuznets's influential hypothesis (Kuznets, 1955), income inequality should have declined spontaneously in advanced capitalist countries, as more and more workers joined the high-paying sectors of the economy.
} 


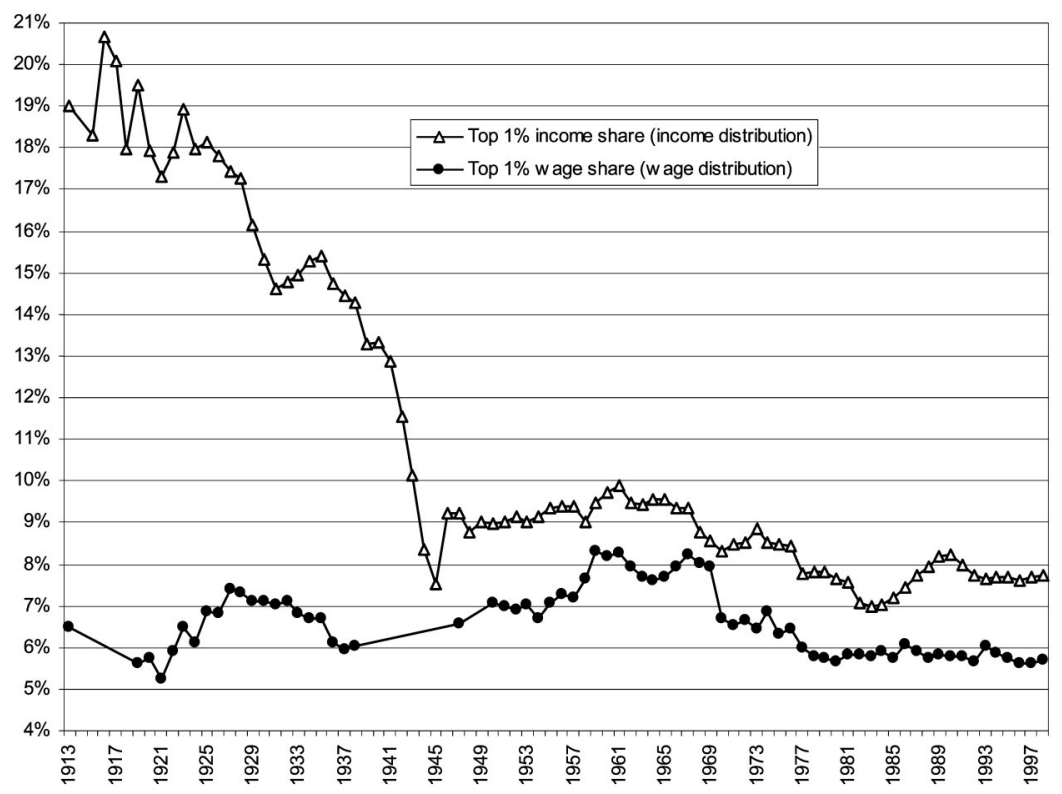

Figure 1. The Fall of Top Capital Incomes in France, 1913-1998

Source: Piketty (2003) (computations based on income tax returns).

dropped between 1914 and 1945 is that top capital incomes fell, whereas top wage shares remained approximately constant (see Figure 1 ). The wealth of the very rich was massively reduced by shocks in the first half of the twentieth century-these included war, inflation, and the Great Depression. The very rich have never fully rebuilt their estates, probably because of the dynamic effects of progressive estate and income taxation on capital accumulation and pre-tax income inequality. A central limitation of these top income and wage shares series is that they begin late-just before World War I. There is no systematic data source on incomes before then because the modern progressive income tax was not created until around 1913 in most countries. ${ }^{3}$ Although these series strongly suggest that the 1914-1945 shocks played the key role, one cannot fully exclude the possibly of a pre-existing, Kuznets-type downward trend in inequality prior to World War I. Constructing

\footnotetext{
${ }^{3}$ The modern income tax was introduced in 1909 in the United Kingdom, in 1913 in the United States, and in 1914 in France.
}

wealth concentration series covering both the nineteenth and the twentieth centuries allows us to put the 1914-1945 period into a broader historical perspective.

A second and equally important goal is to understand the origins of the high levels of inequality that we know prevailed on the eve of World War I. One can consider two extreme hypotheses. The first would suggest that these high levels were longstanding - the result of the political structures of societies where the primary form of wealth was land. The second is that capitalism, and in particular the interconnection between financial development and industrial growth, created new forms of wealth whose distribution was radically unequal. We thus aim to measure both the level of inequality that prevailed prior to the onset of industrialization and the changes that modernization brought forth. Luckily for us, the 1850s form a convenient turning point since industrialization accelerated under the Second Empire (1852-1870) and the stock market boomed (Maurice LéviLeboyer and François Bourguignon, 1985).

Finally, French historical sources on wealth distribution are perhaps the richest in the world 
and ideal to investigate long-term changes in inequality. As early as 1791, the French National Assembly introduced a universal estate tax, which has remained in force since then. This estate tax was universal because it applied at any level of wealth and for nearly all types of property (both real and estate). ${ }^{4}$ Furthermore, the successors of all decedents with positive wealth were required to file a return. The estate tax was made progressive in 1902 (it was strictly proportional from 1791 to 1902), which prompted the French tax administration to start compiling summary tabulations of all individual estate tax returns. 5 These tabulations provide information about the number and value of estates in given wealth ranges. No such tabulations were compiled prior to 1902. However, the tax authorities transcribed individual returns in registers that have been preserved. We used these registers to collect large samples of individual returns between 1807 and 1902. We then constructed homogeneous estimates of wealth concentration in Paris and France from 1807 to 1994 (see below for more details on the data and methodology).

Other scholars have attempted to use these sources to examine the evolution of inequality in France and in Paris. In particular, Adeline Daumard (1973) led a research group that examined a few cross sections of estate returns $(1821,1847$, and 1911) in a small number of cities in France. Although the data collected were extraordinarily detailed, the intervals between samples were too long to uncover the evolution of inequality prior to World War I. Another, ongoing, project follows the descendants of all couples marrying in France between 1800 and 1830 and whose family name started with the letters "TRA" up to 1940 . While this approach yields critical information about the intergenerational transmission of wealth within the broad population, the sample size is too small to study the very wealthy. In fact, the TRA survey contains too few observations to

\footnotetext{
${ }^{4}$ The one glaring exception was government bonds; these were exempted until 1850 .

${ }^{5}$ Prior to 1902 , the tax on estates that devolved to children was a flat 1 percent. In 1902 when the tax became progressive, the top marginal rate was 5 percent; by the mid-1930s it was 35 percent; it remains today at 40 percent (see Piketty, 2001, Appendix J).
}

deliver reliable estimates above the ninety-fifth percentile of the distribution (which is unfortunate, because this is where most of the wealth lies). ${ }^{6}$

In other countries, direct and homogeneous evidence on the evolution of wealth inequality is scarce. For instance, the United Kingdom did not see a universal estate tax before 1894, and the United States waited until 1916. As a result, homogeneous wealth concentration series based upon estate tax returns can cover only the twentieth century in those two countries. ${ }^{7}$ Prior to establishment of estate taxes, scholars relied on other sources, in particular probate records. The information provided by probate records, however, is neither as rich nor as systematic as that contained in estate tax returns (in particular, probate records were purely voluntary, and all types of property were not covered). ${ }^{8}$ Consequently, it is very difficult to compare the eighteenth- and nineteenth-century probate-based estimates to the fiscal-based twentieth-century estimates. Nevertheless, they all suggest that wealth concentration rose during the nineteenth century and dropped during the first half of the twentieth century. In contrast, there is little evidence as to the course of inequality in the late nineteenth century (see, e.g., the survey by Lindert, 2000). Had it started to decline as

\footnotetext{
${ }^{6}$ The TRA survey can be used for other purposes, however. For instance, Bourdieu et al. (2003) use the survey to measure the evolution of the fraction of poor decedents (i.e., decedents with zero or near-zero wealth), and they find that this fraction had been increasing in nineteenth-century France (see below).

${ }^{7}$ The standard references are Atkinson and Alan J. Harrison (1978) for the United Kingdom and Robert J. Lampman (1962) for the United States. Atkinson and Harrison use estate tax return tabulations covering the 19231972 period to compute top wealth share series (the tabulations compiled by the U.K. tax administration over the 1894-1914 period are less rich and do not allow for the same computations as the post-1923 tables). Lampman uses estate tax return tabulations covering the 1922-1956 period to compute top wealth share series (these series have been updated by various authors, including Wojciech Kopczuk and Saez, 2004). See Peter H. Lindert (2000) for a recent survey.

${ }^{8}$ In particular, real estate was not probated in the United Kingdom before 1898 (realty and personalty were also treated differently in U.S. probate records). For estimates of wealth concentration in the United Kingdom based on eighteenth- and nineteenth-century probate records, see Lindert (1986). For corresponding estimates for Colonial America, see Alice H. Jones (1977).
} 
Kutznets would have thought? Did it stabilize? Did it keep increasing until World War I? Our French series allow us to cast new light on this central issue because they are homogeneous over the 1807-1994 period.

Our main conclusions are the following. First, wealth concentration in Paris and in France increased up to World War I, with an acceleration (rather than a stabilization) of the trend at the end of the period. The bulk of the rise in inequality actually took place during the $1860-1913$ period. This was largely driven by the growth of large industrial and financial estates and coincided with the decline of aristocratic fortunes. During the first half of the nineteenth century, the share of aristocrats in top estates actually rose. Next, the decline in wealth concentration observed after World War I appears to have been driven by the 1914-1945 shocks rather than by a two-sector, Kuznetstype process. The decline in inequality was not due to a reduction in the gap between Paris and the provinces, since it occurred both in Paris and in the rest of France. Finally, and perhaps most importantly, the very high levels of wealth concentration observed at the eve of World War I seem to have been associated with retired individuals who had lived off capital income (henceforth rentiers) rather than with active entrepreneurs. In particular, the age-wealth profile of decedents is markedly steeper between 1900 and 1913 than in other periods. Top wealth holders were very old at the turn of the last century (in their seventies and eighties), whereas they are usually in their fifties in other periods, both at the beginning of the nineteenth century and at the end of the twentieth century. Although our data do not allow us to evaluate the inefficiency of wealth concentration directly, these results shed new light on the ongoing debate about inequality and growth. That is, to the extent that credit constraints were important in 1900 France (which we cannot prove directly with our data), our findings about the changing age profile of wealth suggest that high wealth concentration might have been associated with lower growth. ${ }^{9}$

\footnotetext{
${ }^{9}$ One way to test directly for the efficiency impact of high wealth concentration would be to look at investment patterns across wealth fractiles and age groups (i.e., the
}

The paper is organized as follows. Section I describes our data sources and outlines our methodology. Section II presents our estimates of wealth concentration and composition at death in Paris. Section III discusses how the estimates from nineteenth-century Paris can be extended to the rest of France and presents preliminary results for wealth concentration at death in France from 1807 to 1994. Section IV shows how our data on wealth and age at death can be used to estimate series on wealth concentration among the living, using the estate multiplier method. Section V examines age-wealth profiles and discusses the efficiency implications of high wealth concentration. Section VI concludes.

\section{Data Sources}

All of our estimates are based upon estate tax returns. As noted above, the estate tax was created in 1791 and it became a progressive tax in 1902. Since then, the tax administration has periodically compiled tables indicating the number of decedents and the value of their estate for a large number of estate brackets. These tables were already used by Piketty (2001, 2003), and they are available over the 1902-1994 period. $^{10}$ They were compiled and published by département (middle-level administrative jurisdictions; there are about 90 of them in France, including Paris). ${ }^{11}$ These tables can be used to study the evolution of wealth

extent to which older wealth holders invest their wealth in low-yield assets). The sources we use lend themselves to precisely this kind of investigation and we intend to continue this practice in further research.

${ }^{10}$ These tabulations were published in the official statistical publications of the French Finance Ministry (for exact references and page numbers see Piketty, 2001, Appendix J). The basic national tabulation indicating the number of decedents and amount of their estate for a large number of estate brackets is available for the following years: 19021913 (except 1906 and 1908), 1925-1960 (except 1928 and 1934), 1962, and 1964. The French tax administration stopped compiling such tables in 1964, but micro-files including large national samples of estate tax returns are available for 1984 and 1994 (in the present paper, we use only the 1994 micro-file).

${ }^{11}$ Tables by estate brackets are available at the département level for the following years: 1902-1913 (except 1906 and 1908) and 1925-1958 (except 1928 and 1934); for other years, tables by estate brackets are available only at the national level. In addition, national tables broken down by estate brackets and age of decedents are available for years 
Table 1-Estate Tax Returns in Paris, 1807-1994-Summary Statistics

\begin{tabular}{lcccccc}
\hline \hline & $\begin{array}{c}\text { N. decedents } \\
20-\mathrm{yr}+\end{array}$ & N. estate $>0$ & $\begin{array}{c}\text { N. estate }>0 \\
\text { (percent } \\
\text { N. deced. 20+) }\end{array}$ & $\begin{array}{c}\text { N. deced. 20-yr+ } \\
\text { (percent } \\
\text { Paris/France) }\end{array}$ & $\begin{array}{c}\text { Total estate } \\
\text { (percent } \\
\text { Paris/France) }\end{array}$ & $\begin{array}{c}\text { Average estate } \\
\text { (Ratio Paris/rest } \\
\text { of France) }\end{array}$ \\
\hline 1807 & 11,622 & 3,647 & 31.4 & 2.5 & 8.2 & 3.56 \\
1817 & 11,925 & 3,287 & 27.6 & 2.5 & 8.4 & 3.56 \\
1827 & 14,151 & 3,877 & 27.4 & 2.8 & 9.4 & 3.56 \\
1837 & 16,902 & 4,922 & 29.1 & 3.1 & 9.8 & 3.42 \\
1847 & 18,169 & 4,814 & 26.5 & 3.3 & 11.5 & 3.86 \\
1857 & 19,248 & 6,048 & 31.4 & 3.6 & 14.3 & 4.51 \\
1867 & 26,844 & 7,370 & 27.5 & 4.6 & 16.8 & 4.16 \\
1877 & 28,777 & 8,245 & 28.7 & 5.1 & 20.1 & 4.22 \\
1887 & 34,411 & 9,815 & 28.5 & 5.9 & 26.0 & 4.01 \\
1902 & 36,366 & 9,830 & 27.0 & 6.5 & 26.6 & 5.05 \\
1913 & 35,677 & 11,927 & 33.4 & 5.5 & 17.3 & 5.23 \\
1929 & 35,842 & 14,495 & 40.4 & 5.3 & 15.0 & 5.42 \\
1938 & 30,274 & 16,013 & 52.9 & 5.5 & 15.9 & 3.76 \\
1947 & 24,955 & 14,090 & 56.5 & 5.5 & 9.7 & 3.07 \\
1956 & 27,940 & 16,053 & 57.5 & 3.6 & 3.24 \\
1994 & 18,553 & 12,528 & 67.5 & & 256 \\
\hline
\end{tabular}

Source: Authors' computations using estate tax returns (see Piketty et al., 2004, Table A1, for detailed series and sources).

concentration both in France and in Paris during the twentieth century, using standard Pareto interpolation techniques.

Prior to 1902 , the tax administration published only the aggregate amount of wealth reported on estate tax returns, broken down by real (land and buildings) and personal (furniture, businesses, stocks, bonds, etc.) assets. ${ }^{12}$ Studying concentration thus required collecting our own samples of individual returns. Collecting information on every individual return from every département for a given year was impossible. It would have required going to the archives of each département, acquiring access to the registers of each tax bureau (the lowestlevel tax jurisdiction), and dealing with hundreds of thousands of declarations each year. We therefore had to devise a sampling strategy. One option was to select randomly (e.g., on the basis of birth dates or family names) a nationally representative sample of decedents for various years during the nineteenth century. That sample would need to be extremely large, however, to include enough large estates. (Given

1943-1954. The 1994 micro-file also allows us to break down the data by département and age.

12 These published aggregates were computed by the administration on the basis of tax receipts. that wealth is extremely concentrated, it is critical to observe many of the very wealthy.)

Therefore, we decided to pursue a completely different strategy and collected data for all decedents in Paris for selected years $(1807,1817$, $1827,1837,1847,1857,1867,1877,1887$, and 1902). We chose Paris because a disproportionate share of the very rich lived there. As one can see from Table 1, around 1810, the annual number of decedents (20 years old and over) in Paris was about 12,000 (2.5 percent of the French total); that figure nearly tripled during the nineteenth century, to about 35,000 by 1900 (6.5 percent of the French total). However, only 30 percent of decedents in Paris had an estate during the nineteenth century (about half as many as in the rest of France) so we needed only to collect detailed information on 3,500 decedents or so per year at the beginning of the nineteenth century and 10,000 or so decedents per year at the end (see Table 1). Although Paris had more decedents with zero wealth than the rest of the country, the average estate was about 4.5 times larger in Paris than elsewhere in France during the nineteenth century. ${ }^{13}$ It is particularly striking to notice that this ratio actually increased

\footnotetext{
${ }^{13}$ Average estates, as well as top estate fractiles, are always defined in this paper over the set of all decedents aged 20 and older, including those with zero wealth.
} 


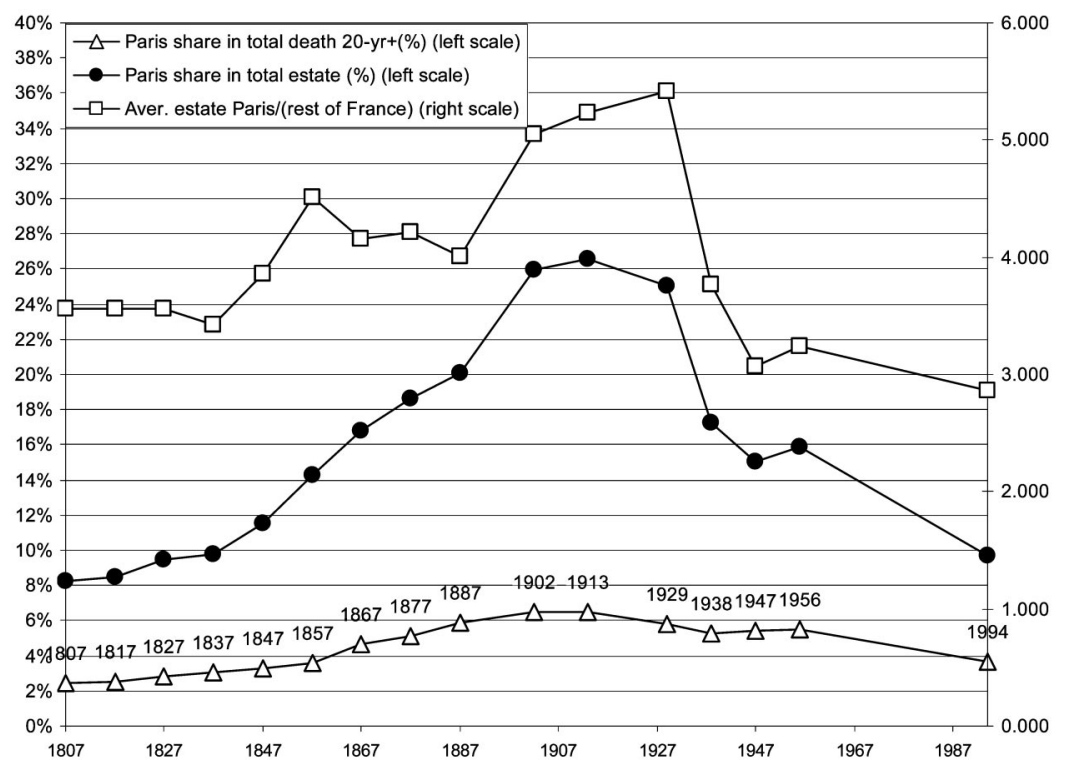

Figure 2. The Paris Share in French Estates at Death, 1807-1994

Source: Authors' computations based on estate tax returns (see Table 1).

over time, in spite of the fact that Paris nearly tripled in population. ${ }^{14}$ On the eve of World War I, the estates of Paris decedents made up over 26 percent of the French total (see Table 1 and Figure 2).

We designed our data collection to take advantage of the work of the estate tax administration. For every person who either died in Paris or might have taxable wealth in any of one of Paris's nine bureaux, the administration opened an entry in a first set of volumes (the tables des successions et absences, henceforth TSA). Later, the entry was completed either when estate taxes were paid or when the administration became satisfied that the individual had left no wealth behind. The entries include name, occupation, residence, marital status, age, and, for individuals with wealth, information about heirs and the date at which the declaration was

\footnotetext{
${ }^{14}$ Note that there is a discontinuity in the growth of Paris during the nineteenth century, as new districts (arrondissements) previously registered in the suburb were integrated into the City of Paris in 1860 . The results reported here do not make any correction for this discontinuity, which explains the discontinuity observed in some of the figures around 1860 .
}

filed. Up to 1870 the TSA also include a summary of the individual's estate broken down into personal wealth and real estate. Hence, the cross sections up to 1867 rely heavily on the TSA. After 1870, the administration no longer recorded wealth information in the TSA but only whether returns had been filed for the individual. For 1877, 1887, and 1902, we started with the TSA and for each individual for whom a return had been filed, we collected the first three letters of the last name, gender, age, day and month of death, and the date(s) at which returns had been filed. We then opened a second set of registers (the registres de mutations par décès, henceforth RMD) where a complete description of the estates is transcribed, and the information not gleaned in the TSA was appended to the first set of entries.

Yet these data gave information by tax return, not by individual. A decedent's heirs could file multiple returns either because they amended their original declaration or, before 1902, because they paid taxes in multiple bureaux. Indeed, prior to 1902, estate taxes on real estate were paid in the bureau of the asset rather than that of the residence of the decedent. In an era of strictly proportional taxation, such dispersed 
payment of taxes reduced administrative costs because information about real estate values did not have to be centralized. Naturally, when the estate tax became progressive in 1902, returns had to be unified. Because TSA entries provide links to the different declarations in the same bureau, reassembling these declarations was easy; reassembling returns from different $b u$ reaux was another matter because there are no links across bureaux. To reassemble fully all individual returns would have required us to collect detailed information on every decedent in Paris. But we did not need to do so because the very high levels of inequality in Paris came to our assistance. By collecting nominal information on the top 10 percent of returns, we were able to attribute successfully 92 percent of movable assets and 97 percent of all real assets to specific individuals. ${ }^{15}$ Given the high variety of first names and last names, as well as detailed information on residence, the likelihood of falsely positive matches is very low. The remaining returns were treated as individuals, thus biasing downward our inequality estimates.

Our 1902 Paris sample is fully consistent with the table compiled by the tax administration for the same year for Paris. Therefore, we can link up our 1807-1902 Paris files with the 1902-1994 Paris tables to construct homogeneous 1807-1994 series for inequality in Paris. The more difficult task is to use the Paris data to infer changes in wealth concentration for France from 1807 to 1902 . To do so, we must estimate how the relative importance of Paris in each top estate class evolved over the nineteenth century. To achieve this goal, we used other estate surveys, ${ }^{16}$ as well as nonestate fiscal sources (see Section III below). The other difficult part is the construction of estimates for wealth concentration among the living from estate tax data, which we do using the estate multiplier method

\footnotetext{
15 To check our procedure for $1817,1827,1877$, and 1887 , we also assembled all declarations that matched on the first three letters of last name, gender, day of death, and age; the estimates of inequality are slightly higher but trivially so.

${ }^{16}$ In addition to the TRA survey (which gives a reliable picture of the national distribution up to the ninety-fifth percentile), we should mention the study by Daumard (1973), which relied on samples of estate tax returns collected in five French cities at the beginning and at the end of the nineteenth century (we shall come back to this important study below).
}

and mortality data by age group (see Section IV below).

When using tax data, it is also important to keep in mind that tax evasion and manipulation can potentially bias the results. There are, however, good reasons to believe that this is not too much of a problem here. First, estate tax rates were extremely modest until World War I (less than 2 percent), which implies that the incentives for tax evasion were small. In contrast, penalties for evasion were stiff. Moreover, the administration made every effort to keep up with changing composition of assets and to track down individuals with some wealth. Among other things, financial institutions and public utilities were required to notify the administration when accounts changed owners. As a result, it was not easy to dissimulate the wealth of a decedent (either real estate or financial assets in a publicly traded firm), and inheritors had a strong incentive to register their property in order to benefit from state protection. This suggests that the nineteenth-century data collected in the Paris archives is probably of very high quality. Tax evasion is potentially a more serious issue for the twentieth century, when tax rates become substantial. Although top estate tax rates have rarely exceeded 20 to 30 percent for direct transmissions in France (the top rate has been 40 percent since 1984, its highest level ever), it is obvious that incentives for tax evasion have increased over time. However, several independent data sources suggest that the trends observed during the twentieth century are robust and are not due to the rise of tax evasion. ${ }^{17}$

\section{Wealth Concentration at Death in Paris, 1807-1994}

Figure 3 shows the evolution of wealth concentration at death in Paris from 1807 to 1994. Given that the bottom two thirds of the distri-

\footnotetext{
${ }^{17}$ See Bourdieu et al. (2004). Furthermore the twentiethcentury decline in wealth concentration observed in estate tax returns is qualitatively and quantitatively consistent with the decline in capital income concentration observed in income tax returns (and the latter appears to be robust; in particular, it holds after scaling up tax-return capital income using national accounts aggregates). This is also consistent with several other data sources on wealth concentration and top fortunes (especially equity ownership data). See Piketty (2001, 2003) for a detailed discussion.
} 


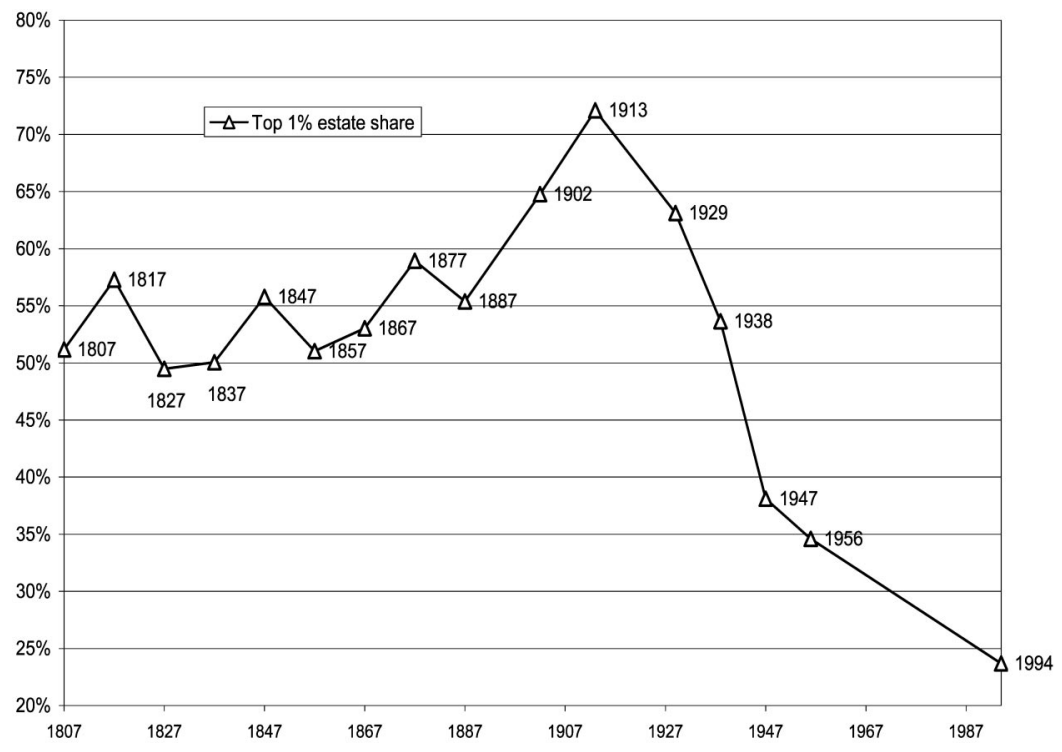

Figure 3. Wealth Concentration at Death in Paris, 1807-1994

Source: Authors' computations based on estate tax returns (see Table 2).

bution own no wealth and the richest decile accounts for at least 95 percent of the value of all assets during the nineteenth century (see Table 2), we focus on the top 1 percent. The richest 1 percent of (adult decedents) Parisians appears to have held a stable and very high fraction of all assets during the first half of the nineteenth century (around 50 to 55 percent of total wealth). The 1817 spike was short-lived and was due not to a large increase in the size of top estates, but rather to a large decline in modest estates (which apparently suffered the most from the Napoleonic Wars). ${ }^{18}$ Inequality in Paris increased substantially after 1867 with the top-1-percent share of wealth at death

${ }^{18}$ Other spikes in the top-1-percent share are due for the most part to the volatility of the very top estates (the top-0.1-percent share, and mostly the top-0.01-percent share). Note that with about 20,000 decedents per year in Paris, the top-0.1-percent fractile includes only 20 decedents, and the top 0.01 percent only 2 decedents, so that the estimates for these fractiles are unstable. They depend on the identity of very wealthy individuals who happened to die in a specific year. The figures reported in Table 2 are the raw figures, with no adjustment whatsoever for this top wealth volatility. Note, however, that the 1867-1913 upward trend is highly significant and does not rely on a small number of very top wealth holders.
Table 2-Wealth Concentration at Death in Paris, 1807-1994

\begin{tabular}{lccc}
\hline \hline & $\begin{array}{c}\text { Top-10-percent } \\
\text { estate share }\end{array}$ & $\begin{array}{c}\text { Top-1-percent } \\
\text { estate share }\end{array}$ & $\begin{array}{c}\text { Top-0.1-percent } \\
\text { estate share }\end{array}$ \\
\hline 1807 & 96.0 & 51.2 & 17.9 \\
1817 & 97.6 & 57.3 & 22.8 \\
1827 & 97.3 & 49.5 & 14.8 \\
1837 & 97.7 & 50.1 & 14.8 \\
1847 & 98.3 & 55.8 & 21.3 \\
1857 & 96.9 & 51.0 & 13.4 \\
1867 & 97.1 & 53.0 & 16.3 \\
1877 & 96.9 & 58.9 & 24.6 \\
1887 & 97.1 & 55.4 & 20.1 \\
1902 & 99.1 & 64.8 & 26.1 \\
1913 & 99.6 & 72.1 & 32.8 \\
1929 & 94.9 & 63.1 & 26.4 \\
1938 & 90.4 & 53.6 & 24.1 \\
1947 & 76.7 & 38.1 & 14.8 \\
1956 & 75.0 & 34.6 & 11.7 \\
1994 & 66.9 & 23.7 & 6.5 \\
\hline
\end{tabular}

Source: Authors' computations using estate tax returns (see Piketty et al., 2004, Table A2, for detailed series and sources).

climbing from about 52 percent to over 72 percent in 1913. World War I and the ensuing shocks then prompted an abrupt decline. The top-1-percent share dropped by 34 percentage points between 1913 and 1947 and by about 10 


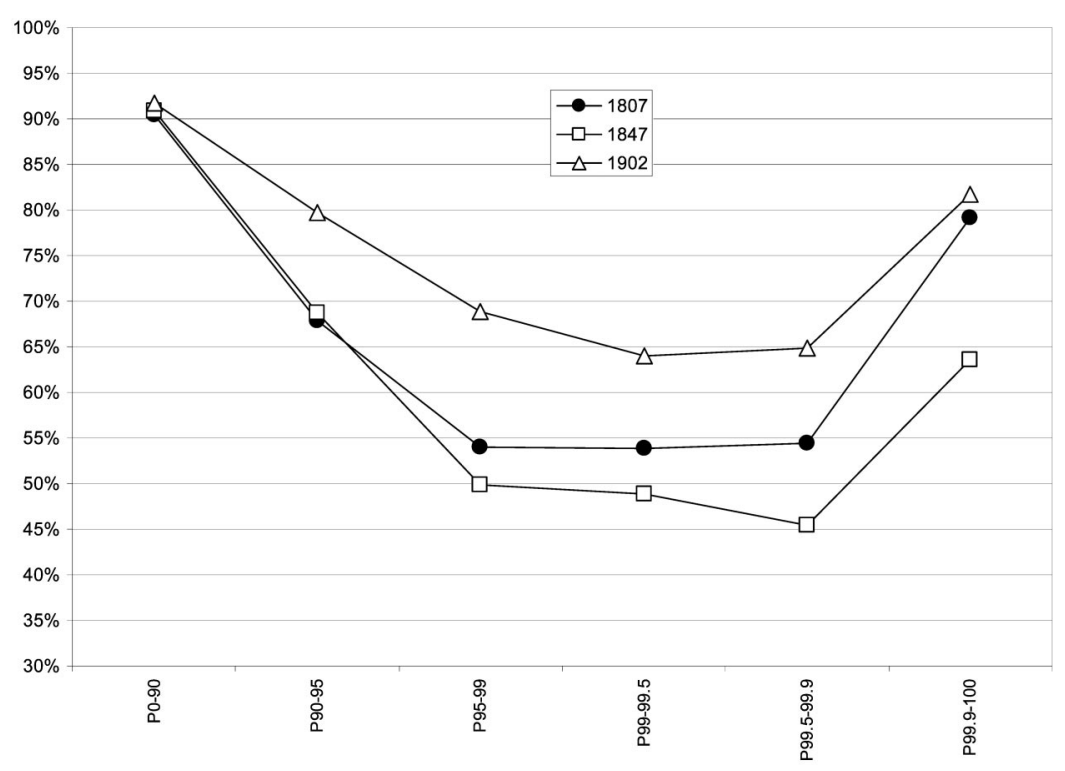

Figure 4. Wealth Composition at Death in Paris, 1807-1902

(Share of personal (non-real) estate in total estate)

Source: Authors' computations using samples of estate tax returns collected in the Paris archives.

percentage points between 1956 and 1994. Converting these wealth-at-death concentration estimates into wealth-of-the-living concentration estimates leaves this general picture unchanged (see Section IV below).

Who were the individuals who enjoyed such a substantial increase in their relative wealth between 1867 and 1913? For the most part, their fortunes derived from large industrial and financial estates. As Figure 4 illustrates, the share of personal (non-real) estate has always been a U-shaped function of wealth. This reflects the well-known fact that real estate is a middleclass asset. The poor are too poor to own land or buildings; what little they have is in furniture, cash, or other moveable items. In contrast, the rich hold most of their wealth in stocks and bonds. What is more interesting is that during the nineteenth century the relative importance of personal wealth in Parisian estates also followed a U-shaped curve over time. This was especially true for the very wealthy (see Figures 4 and 5) where real assets became more and more important from 1807 to 1837 . Real estate then entered a relative decline after 1837 , and accelerated after 1867.
The ebb and flow of the relative importance of real estate was linked to Paris's recovery from the French Revolution. Prior to the Revolution, the peripheral parts of the city had been a maze of convents, monasteries, and educational institutions all belonging to the Catholic Church. When the wealth of the Church was nationalized, these real estate assets were abruptly put on the private market, creating a glut of buildings and low prices. As the city's population expanded, building and land values recovered, and the relative importance of real estate grew, before being overshadowed by the financial boom of the last part of the century (Michel Lescure, 1982).

The share of aristocratic decedents among the very rich follows an inverted-U-shaped curve over the nineteenth century (see Figure 6). ${ }^{19}$ That is, nobles became more and more numerous in top wealth fractiles from 1807 until 1847 , then the trend reversed and their impor-

\footnotetext{
${ }^{19}$ We take a very broad view of aristocrats: they include the Old Regime nobility, the members of the elite who were given titles by Napoleon (1801-1814), and the Bourbons (1815-1830).
} 


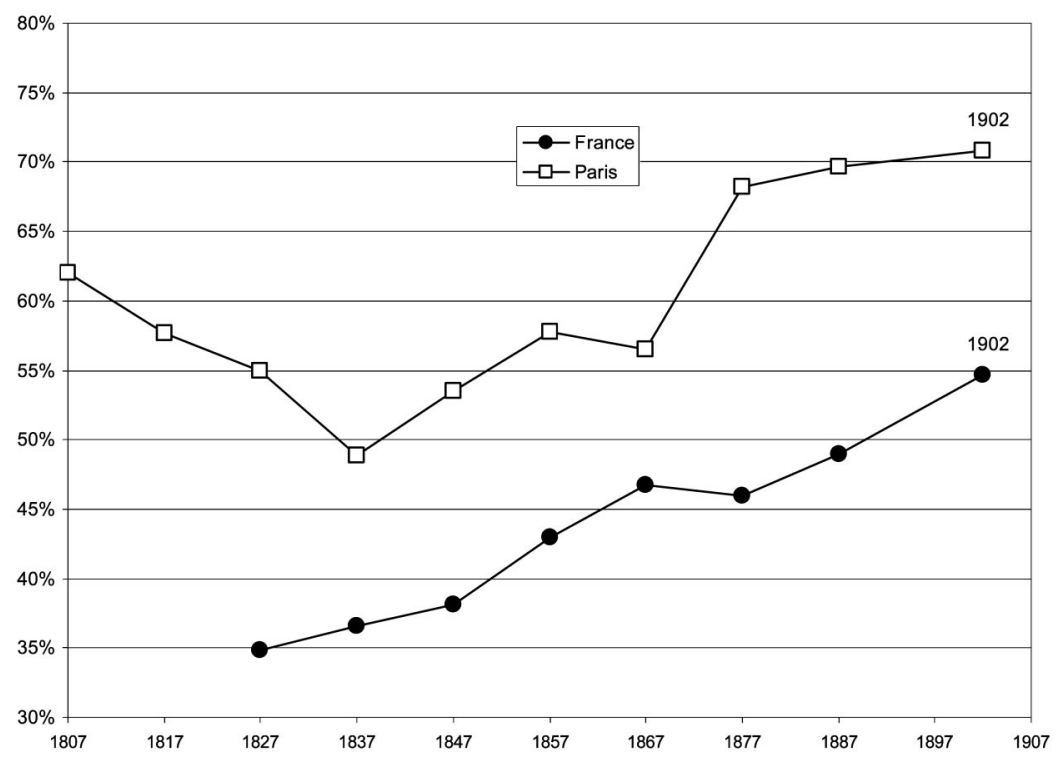

Figure 5. Wealth Composition at Death in Paris and France, 1807-1902

(Share of personal (non-real) estate in total estate)

Source: Authors' computations using samples of estate tax returns collected in the Paris archives and national aggregate estate statistics compiled by the French tax administration.

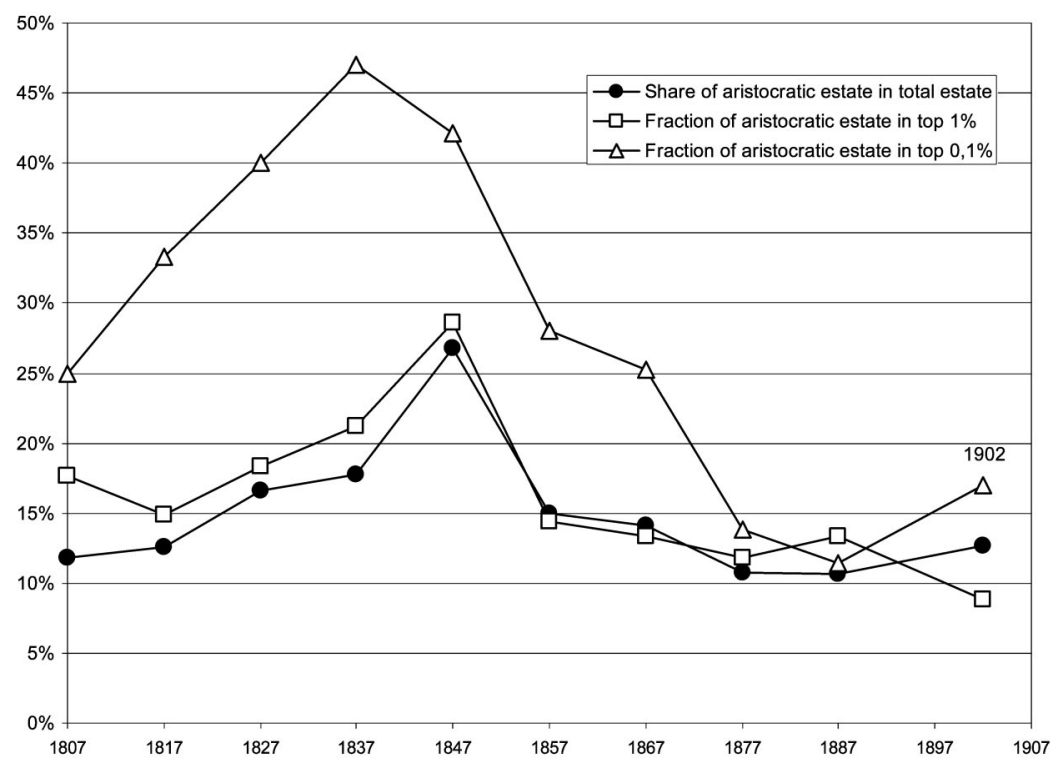

Figure 6. Aristocratic Estates at Death in Paris, 1807-1902

Source: Authors' computations using samples of estate tax returns collected in the Paris archives. 


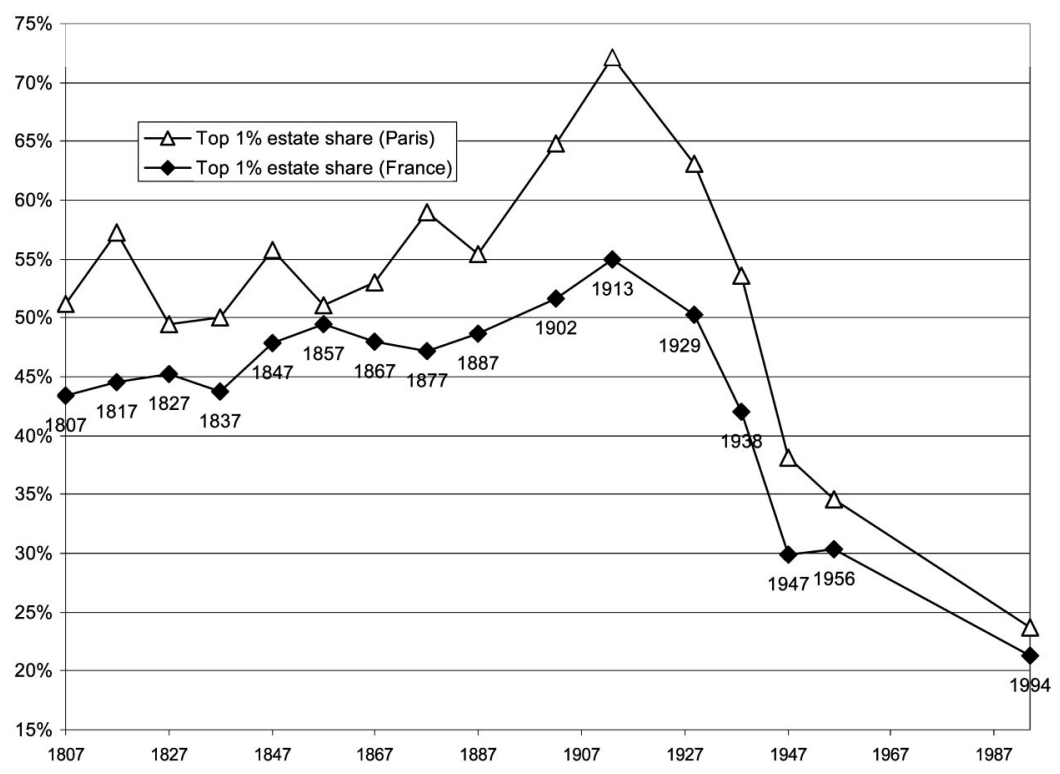

Figure 7. Wealth Concentration at Death in Paris and France, 1807-1994 Source: Authors' computations based on estate tax returns (see Tables 2 and 4).

tance declined steadily. To be sure, aristocrats remain overrepresented throughout the period, including in 1902 (about 13 percent of nobles in the top 1 percent of estates, over 25 percent in the top 0.1 percent, versus less than 1 percent in the population as a whole). The inverted-U pattern is yet another of the Revolution's legacies. In 1807, when we first observe it, aristocratic wealth was at a temporary nadir. On the one hand, the nobility was impoverished by the Revolution's inflation and by the sharp decline of the value of Parisian real estate. On the other hand, part of the Old Regime nobility was in exile and thus, if they died, we do not observe their moveable wealth. Aristocrats were able to recoup part of their losses during the first half of the nineteenth century. Napoleon provided some assistance by conferring titles of nobility on his chief military officers and endowing them with wealth. Later, the Restoration government (1815-1830) compensated individuals who fled abroad during the Revolution for the losses they suffered when their property was confiscated. The government distributed nearly one billion francs in the famous milliard des emigrés (André Gain, 1929). The beneficiaries of Napoleon's and the Restoration's largess ap- pear among the very rich until mid-century. Presumably such redistribution did not contribute to accelerate French industrialization.

\section{From Paris to France}

We can use the Paris data to construct wealth concentration at death estimates for all of France from 1807 to 1902 . To do so, we need to know the evolution of the share of Paris estates in top estates. Between 1902 and 1994, available data (broken down by département) shows that the evolution of top estate shares in France was parallel to that of top estate shares in Paris. Wealth inequality is always lower for the country as a whole, but the trends are similar (see Figure 7). It is also striking to note that Paris's share of the top 1 percent of French estates has remained fairly stable over the twentieth century (it fluctuates between 20 percent and 25 percent, with no trend), even though Paris's share of all decedents has been dwindling over time, reflecting the population decline of the capital (see Table 3). In 1902, Paris decedents were four times more likely to belong to the national top 1 percent of estates than average decedents $(26.6 / 6.5=4.1)$; in 1994, Paris de- 
Table 3-The Fraction of Paris Estates in Top Estates at Death in France, 1807-1994

\begin{tabular}{lcccc}
\hline \hline & $\begin{array}{c}\text { (1) Fraction of Paris } \\
\text { decedents in all } \\
\text { decedents 20-yr+ }\end{array}$ & $\begin{array}{c}\text { (2) Fraction of Paris } \\
\text { estates in top-10- } \\
\text { percent estates }\end{array}$ & $\begin{array}{c}\text { (3) Fraction of Paris } \\
\text { estates in top-1- } \\
\text { percent estates }\end{array}$ & $\begin{array}{c}\text { (4) Fraction of Paris } \\
\text { estates in top-0.1- } \\
\text { percent estates }\end{array}$ \\
\hline 1807 & 2.5 & & 10.1 & 20.5 \\
1817 & 2.5 & & 10.3 & 21.0 \\
1827 & 2.8 & & 11.6 & 23.7 \\
1837 & 3.1 & & 12.6 & 25.6 \\
1847 & 3.6 & & 14.6 & 29.7 \\
1857 & 3.6 & & 14.6 & 29.7 \\
1867 & 4.9 & & 19.9 & 40.4 \\
1877 & 5.1 & & 21.1 & 42.8 \\
1887 & 5.9 & 7.5 & 24.1 & 49.1 \\
1902 & 6.5 & 26.6 & 54.1 \\
1913 & 6.5 & 8.3 & 25.5 & 52.3 \\
1929 & 5.8 & 7.4 & 23.9 & 53.0 \\
1938 & 5.3 & 11.0 & 21.6 & 42.1 \\
1947 & 5.5 & 12.8 & 19.8 & 35.2 \\
1956 & 5.5 & 8.9 & 22.3 & 35.0 \\
1994 & 3.6 & & 25.2 & 35.2 \\
\hline
\end{tabular}

Source: Authors' computations using estate tax returns (see Piketty et al., 2004, Table A1, for detailed sources). No data source exists to compute columns (3)-(4) prior to 1902, and the numbers reported on this table for years 1807-1887 were computed assuming that the columns (3)-(4) followed the same trend as column (1) over the 1807-1902 period (see text, Section III).

cedents were seven times more likely to belong to the national top 1 percent of estates than average decedents $(25.2 / 3.6=7.0)$. If anything, the geographic concentration of fortunes was larger at the end of the twentieth century than at the beginning. The decline of wealth concentration that followed World War I was not due to redistribution between Paris and the provinces.

How did the fraction of Paris estates in top estates evolve over the course of the nineteenth century? Our estimates rely on a simple and very conservative assumption: from 1807 to 1902, Paris's share of estates in the top percentile increased at the same rate as Paris's share of French adult deaths. More precisely, let us denote $F_{P t}(w)$ the cumulative distribution function for wealth-at-death in Paris in year $t, F_{t}(w)$ the corresponding distribution for France, $n_{P t}$ the total number of adult deaths in Paris in year $t$, and $n_{t}$ the corresponding number for all of France. The ninetieth-percentile threshold $P 90_{P t}$ is defined by $F_{P t}\left(P 90_{P t}\right)=0.9$, the ninety-ninthpercentile threshold $P 99_{P t}$ is defined by $F_{P t}\left(P 99_{P t}\right)=0.99$, etc., and similarly for the French thresholds $P 90_{t}, P 99_{t}$, etc. We observe $F_{P t}(w), n_{P t}$, and $n_{t}$ throughout the 1807-1994 period, but we do not observe $F_{t}(w)$ until 1902 (before this date we observe only national ag- gregate average wealth $\left.w_{t}=W_{t} / n_{t}\right)$. To construct our benchmark estimates, we assume that the shares $s_{99 t}, s_{99.5 t}, s_{99.9 t}$, and $s_{99.99 t}$ of Paris estates in the national top 1 percent, 0.5 percent, 0.1 percent, and 0.01 percent of the national wealth-at-death distribution increased at the same rate as $n_{P t} / n_{t}$ during the 1807-1902 period (see Table 3). Using this approximation and our Paris samples of individual tax returns, we compute the threshold wealth levels for the top percentiles of the national wealth distribution (e.g., P99, P99.5, P99.9, and P99.99). ${ }^{20} \mathrm{We}$ also calculate the average wealth levels for the relevant wealth classes (e.g., P99-99.5, P99.599.9, P99.9-99.99, and P99.99-100) using Pareto interpolation techniques. These are then weighted by the number of individuals in France in that wealth class in order to compute

\footnotetext{
${ }^{20}$ For instance, the number of decedents (aged 20 years and older) in France was 583,976 in 1887 (see Piketty et al., 2004, Appendix Table A1), so that the top 1 percent of the estate distribution at death consists of the top 5,840 estates. If the share of Paris among French top-1-percent estates was 24.1 percent in 1887 (see Table 3), then the national $P 99$ threshold for 1887 corresponds to the top 1,410 Parisian estates $(0.241 \times 5,840=1,410)$ (the national $P 99$ threshold for 1887 reported in Piketty et al., 2004, Appendix Table A3, was computed using this formula).
} 
Table 4-Wealth Concentration at Death in France, 1807-1994

\begin{tabular}{cccc}
\hline \hline & $\begin{array}{c}\text { Top-10-percent } \\
\text { estate share }\end{array}$ & $\begin{array}{c}\text { Top-1-percent } \\
\text { estate share }\end{array}$ & $\begin{array}{c}\text { Top-0.1-percent } \\
\text { estate share }\end{array}$ \\
\hline 1807 & 79.1 & 43.4 & 16.3 \\
1817 & 81.0 & 44.5 & 18.1 \\
1827 & 82.4 & 45.2 & 16.3 \\
1837 & 79.6 & 43.8 & 14.7 \\
1847 & 81.6 & 47.9 & 18.4 \\
1857 & 82.9 & 49.5 & 17.4 \\
1867 & 81.0 & 48.0 & 17.4 \\
1877 & 83.8 & 47.1 & 20.1 \\
1887 & 83.9 & 48.7 & 19.2 \\
1902 & 83.9 & 51.6 & 23.1 \\
1913 & 86.3 & 54.9 & 26.0 \\
1929 & 82.0 & 50.2 & 24.7 \\
1938 & 77.6 & 42.0 & 19.9 \\
1947 & 69.9 & 29.9 & 11.0 \\
1956 & 69.4 & 30.4 & 11.0 \\
1994 & 61.0 & 21.3 & 6.3 \\
\hline
\end{tabular}

Source: Authors' computations using estate tax returns (see Piketty et al., 2004, Table A3, for detailed series).

the average wealth levels for top fractiles ( $P 99$ 100, P99.5-100, P99.9-100, and P99.99-100). Lower thresholds of the national wealth distribution (P90 and P95) were computed using the national TRA survey, ${ }^{21}$ and the $P 90-95$ and P95-99 intermediate wealth levels were also computed using Pareto interpolation techniques.

The national top estate shares estimates reported in Table 4 were computed using this methodology. They suggest that wealth concentration (as measured by the top-1-percent estate share) rose throughout the nineteenth century in France, during both the 1807-1867 and 18671902 periods, although less sharply than in Paris during the latter period (see Figure 7). These estimates are conservative in the sense that it is almost certain that they underestimate the rise of wealth concentration that took place in France during the nineteenth century. First, we know that the bulk of population growth in Paris during the nineteenth century was due to the annexation of suburbs in 1860 and to population growth in these peripheral arrondissements. Be-

\footnotetext{
${ }^{21}$ See Bourdieu et al. (2003) for full details about the TRA survey. The $P 90$ and $P 95$ thresholds reported on Piketty et al. (2004, Appendix Table A3) were computed using ten-year moving averages around the target years in order to make sure that each estimate was based on a sufficient number of observations.
}

cause the outskirts of the city were poor, the annexation added few top estates. Thus, there is little doubt that Paris's share of top estates in France actually increased less than its share of the total population. This hypothesis is confirmed by nineteenth-century housing tax tabulations showing that the fraction of Paris taxpayers in the national top 1 percent of taxpayers was substantially larger than 10 percent at the beginning of the nineteenth century. ${ }^{22}$ Giving Paris a larger (and more realistic) share of top estates in 1807 would both reduce the share of wealth of the top 1 percent in France at that date and lead to more rapid rise in inequality over time.

Next, and most importantly, other estate surveys are consistent with the view that wealth inequality was growing. The important study by Adeline Daumard (1973), which relied on samples of estate tax returns collected in Paris, Lyon, Toulouse, Lille, and Bordeaux, found that wealth concentration increased in each of these five cities during the nineteenth century. ${ }^{23}$ The TRA survey, although it is ill-suited for the study of top estates, is also consistent with our view. Wealth dispersion was on the rise in nineteenth-century France according to the TRA survey, both in the sense that the fraction of decedents with positive estates declined over time (in spite of the sharp increase in the value of the average estate) and that ratios such as the $P 90 / P 50$ increased. $^{24}$ We also compared our benchmark national $P 99$ series extrapolated from our Paris samples, and the national P99 series computed using the TRA survey. We found that both series display the same overall upward trend in concentration (which is reassuring regarding the general validity of our Paris-France extrapolation technique), except that the growth of inequality from 1807 to 1902 in the TRA series is

\footnotetext{
22 These tabulations were published in the same Finance Ministry official publications as the estate tabulations. We chose not to use them in our formal computations because the tax base of the housing tax (namely, the rental value of the real estate property where the household lives) is only loosely connected to the estate tax base (in particular, one cannot rule out the possibility that the housing tax base overrepresents Paris-based taxpayers).

${ }^{23}$ Unfortunately, Daumard's samples are not available in machine-readable format, she has only two or three years of data for each city, and she did not try to compute homogenous inequality indicators (top fractiles shares, etc.) with her data. Thus, although her results and our work are consistent, they cannot be compared directly.

${ }^{24}$ See Bourdieu et al. (2004).
} 


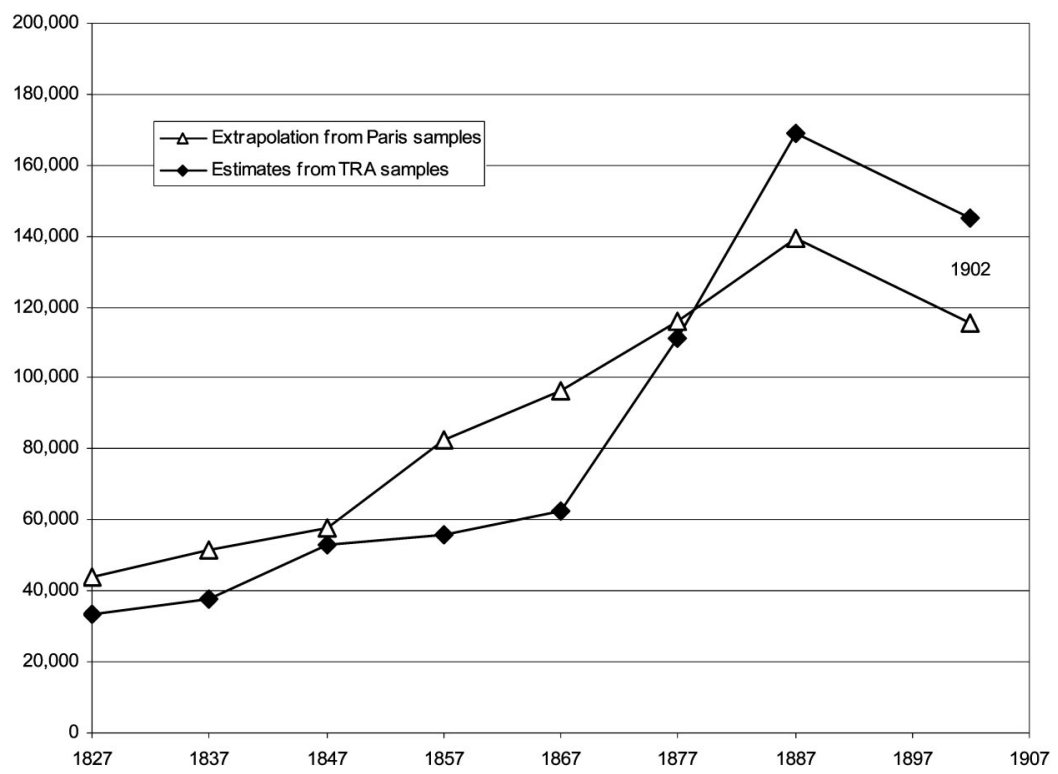

Figure 8. Estimates of the P99 Threshold for the French Distribution of Estates at Death: Extrapolation From PARIS SAMPLES VERSUS EstimATES FROM TRA SAMPLES (CURRENT FRENCH FRANCS)

Source: Authors' computations based on estate tax returns (Paris samples and TRA samples).

more severe than in our series (see Figure 8). This again suggests that the latter provide a conservative lower bound for the upward trend in wealth concentration. In any case, the finding of a large increase in wealth inequality in nineteenth-century France (and up until World War I) appears to be robust. $^{25}$

\footnotetext{
${ }^{25}$ Note that this continuous rise in wealth inequality does not necessarily imply that a parallel rise occurred regarding income inequality. Given that there exists no micro source on incomes prior to the creation of the income tax in 1914, it is very difficult (if not impossible) to properly address this issue. Christian Morrisson and Wayne Snyder (2000) have attempted to link income inequality estimates based upon Old-Regime fiscal sources (pre-1789) with modern, income-tax-based twentieth-century estimates, and they have argued that income inequality might have started to decline during the later part of the nineteenth century and on the eve of World War I (see also Morrisson, 2000). Although our data do not allow us to rule out such a possibility, we note that their nineteenth-century personal distribution estimates are based on fragile macroeconomic data on functional distribution and are not homogenous to their eighteenth- and twentieth-century estimates. Given the evidence that we provide on wealth inequality, any significant decline in aggregate income inequality would have to be associated with severe compression of the wage distribution. There is little research on this issue, however.
}

As was mentioned earlier, there exists no comparable continuous data source covering the nineteenth and twentieth centuries in other countries, which makes it difficult to put our French long-run series in international perspective. We note, however, that existing series for the United States and the United Kingdom are consistent with our findings on France. ${ }^{26}$ Regarding levels, existing evidence suggests that during the nineteenth and most of the twentieth centuries, France was in an intermediate position in terms of wealth concentration, in between the United States (more equal) and the United Kingdom (the most unequal). ${ }^{27}$ These

\footnotetext{
${ }^{26}$ Lee Soltow and Jan L. Van Zanden (1998) also find a decline in inequality in the twentieth century in the Netherlands. Their data are consistent with a rise in inequality in the nineteenth century, but they have no direct evidence about its extent.

${ }^{27}$ According to our series, the top-1-percent wealth share in France rose from around 45 percent in 1800 to about 55 percent around World War I, and then fell to about 20 percent by the end of the twentieth century (see Figure 7); wealth concentration among the living appears to be somewhat larger (see Section V below). According to the series pieced together by Lindert (2000, pp. 181-82 and 186), the U.K. top-1-percent wealth share rose from about
} 
differences in inequality largely hark back to differential concentration of landownership. England's land was extremely narrowly held, while the United States was most egalitarian. The impact of access to real estate assets can also be seen when we contrast Paris (where it was extremely concentrated) with the provinces.

Trends in inequality over time may be easier to compare because biases in source material may have a significant effect on levels rather than trends. The historical pattern is similar in each of the three economies. In particular, there is evidence that wealth concentration increased during the nineteenth century in both AngloSaxon countries, and declined during the twentieth century, with a turning point around World War I. ${ }^{28}$ Neither exhibits patterns consistent with a Kuznet process.

\section{From the Wealth of the Decedents to the Wealth of the Living}

The estimates reported thus far refer to inequality among decedents, as described in the tax returns filed by their heirs. The evolution of the distribution of wealth among the living might, however, have followed a different pattern. In order to convert wealth-at-death concentration estimates into wealth-of-the-living concentration estimates, it is standard to use the "estate multiplier" method. ${ }^{29}$ It consists of weighting each observation of an estate at death

\footnotetext{
55 percent in 1800 to 70 percent around World War I, then fell to about 20 percent in the 1990s. The U.S. top-1-percent wealth share rose from about 15 to 20 percent in 1800 to about 40 percent around World War I, then fell to about 30 percent in the 1990s (and as low as 20 to 25 percent according to the more recent estimates from Kopczuk and Saez, 2004). Wealth concentration is now larger in the United States than in European countries, but the reverse was true during the nineteenth century up until World War II. (It is only since the 1950s-1970s period that U.S. wealth concentration has been somewhat larger).

${ }^{28}$ See Lindert (2000, pp. 181-82 and 188).

${ }^{29}$ This method was widely used in England and France in the late nineteenth and early twentieth centuries to compute the stock of national wealth on the basis of the flow of wealth transmitted at death. Standard references that use this technique to estimate the wealth distribution of the living from estate tax data tabulated by estate size and age at death include Atkinson and Harrison (1978) and Lampman (1962). For a more recent application of this technique to the United States, see Kopczuk and Saez (2004).
}

by the inverse of the mortality rate for this age group. That is, if the mortality rate for ages 20 to 24 was 0.68 percent in Paris in 1902, then each decedent aged 20 to 24 represented about 147 living individuals of the same age (1/ $0.0068=147)$. Similarly, if the mortality rate for ages above 80 was 21.43 percent in Paris in 1902 , then each decedent in that group represented about 4.7 living individuals in the same age group $(1 / 0.2143=4.7)$. Applying this method requires mortality tables (these are easily available) and estate tabulations broken down by estate size and age at death (these are scarcer). Fortunately, the city's statistical $b u$ reau published annual death-by-age totals, the French censuses report the age distribution for the capital every five years, and we collected age at death from the estate declarations. These data allowed us to compute estimates of wealth concentration among the living over the 18071902 period, using various assumptions about the wealth profiles of mortality rates.

The base population for the living is the set of all individuals aged 20 and over living in Paris in year $t$, which we denote $p_{t}$. The number of living individuals in age bracket $a$ is denoted $p_{t a}$ $(a=20-24,25-29,30-34, \ldots, 75-79,80$ and over), and the number of decedents in age bracket $a$ is denoted $n_{t a}$. The mortality rate for age bracket $a$ is given by $m_{t a}=n_{t a} / p_{t a}$. We begin with a uniform-mortality benchmark. These estimates are based on the simplifying assumption that these mortality rates depend solely on age and are the same for all wealth groups (and, in particular, are the same for zero-wealth and positive-wealth individuals). We can then weigh each decedent with positive estate and age $a$ collected in the Paris archives in year $t$ by $p_{t a} / n_{t a}$. This allows us to compute the number of living Parisians with positive wealth in year $t$, and also (by differentiating with $p_{t}$ ) the number of living Parisians with zero wealth at year $t$, which is used to weight zeroestate observations. We then use our weighted datasets to compute top estate fractiles among the living in Paris.

The main conclusion is that the living experienced the same upward trend in wealth concentration as the decedents (see Figure 9). We find that inequality was significantly higher among the living than among decedents, because survivors were, on average, younger than 


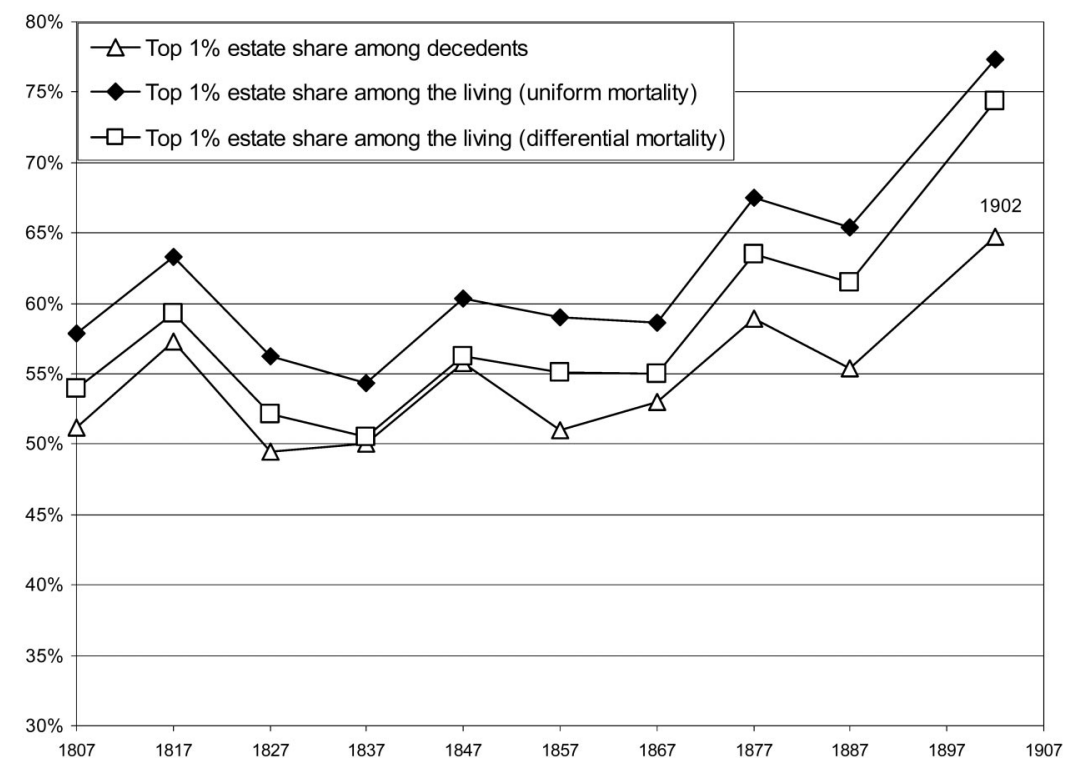

Figure 9. Wealth Concentration among Decedents and among the Living in Paris, 1807-1902

Source: Authors' computations using samples of estate tax returns collected in the Paris archives (see Piketty et al., 2004, Table A4, for detailed series).

those who died, and the young were, on average, poorer. In particular, the estate multiplier method leads to lower average weights for positive-wealth decedents than for zero-wealth decedents (the former are on average older and therefore "represent" a smaller number of living individuals). As a result, the fraction of positivewealth individuals is even smaller among the living than among decedents. Hence, our benchmark uniform-mortality estimates of wealth concentration among the living are significantly larger than corresponding estimates among decedents (e.g., top-1-percent wealth shares are about 15 percent larger among the living). Changes over time, however, are similar. Increased life expectancy and declining mortality rates over the course of the nineteenth century have only a small effect on the trends.

In order to make the estate multiplier method more reliable, one would prefer to take into account differential mortality by wealth. Doing so would require having access to mortality schedules based both on wealth and age at different points in time; unfortunately these are not available. We have, nonetheless, reestimated wealth of the living based upon the same assumption as Kopczuk and Saez (2004). That is, we assumed uniform mortality among the poor (here defined as zero-wealth individuals) and among the rich (here defined as positive-wealth individuals), and we assumed that the ratio $m_{t a R} / m_{t a P}$ between the mortality rate of the rich and the mortality rate of the poor followed a U-shaped age profile, from about 85 percent for the young (i.e., the rich die 15 percent less often than the poor when they are 20-24 or 25-29 years old) down to about 70 percent for middleage individuals in their forties to fifties, and up to 100 percent for very old individuals in their eighties to nineties. ${ }^{30}$ This profile corresponds to the best available estimates in the literature, and it appears to be relatively stable over time and across developed countries. In the absence of better data, it is the best one can do. ${ }^{31}$ The benchmark differential-mortality estimates reported on Figure 9 show that although adding differential mortality produces different levels of inequality, it does not have much impact on the upward trend in concentration.

${ }^{30}$ See Kopczuk and Saez (2004, Table A4).

${ }^{31}$ See Kopczuk and Saez (2004, Appendix B) for references to the U.S. and international literature devoted to the age-wealth profile of mortality rates. 
The resulting differential-mortality inequality estimates lie between those based on decedents only and those using uniform mortality for the living (see Figure 9). Note that moving from uniform-mortality to differential-mortality estate multiplier methodology can either increase or decrease inequality. Here the reason why such a move leads to lower wealth concentration seems to be due to the fact that differential mortality tends to put higher weights on positive-wealth decedents (for a given age), thereby increasing the estimated fraction of living individuals with positive wealth. The important point, however, is that the resulting level effects are relatively small in magnitude, constant in time, and dwarfed by the upward time trend. Even if we were to assume an enormous increase in differential mortality during the nineteenth century, in the sense that differential mortality between the rich and poor was equal to 0 percent of the benchmark differential in 1807 and 100 percent of the benchmark differential in 1902, the resulting wealth concentration estimates would still be significantly higher in 1902 than in 1807 (see Figure 9). Yet we have no reason to believe that differential mortality increased to such an extent. During the nineteenth century real wages for unskilled workers rose, which would have reduced mortality more for the poor than for the rich. After 1850 , public health measures (sanitation, water, vaccination) were in place. Again these would have had a significant effect on the poor and the middle class, who could not privately purchase such health-improving services. To be sure, the rich could avail themselves of more medical services than the poor or the middle class, but the impact of these services was probably small (bear in mind that neither antibiotics nor cardiovascular interventions were available).

Finally, we have applied the estate multiplier method to available data for 1947 and 1994. Overall, the sharp decline in wealth concentration observed during the twentieth century (and especially between 1914 and 1945) is very robust. If anything, the decline appears to be even larger when one looks at wealth concentration among the living rather than among decedents. ${ }^{32}$

\footnotetext{
${ }^{32}$ See Piketty et al. (2004, Table A4). It is unfortunately not possible to construct complete series for wealth concen-
}

\section{The Changing Age Profile of Wealth}

In the previous sections we focused almost exclusively on aggregate top wealth shares. Our data, however, also detail the characteristics of each decedent, in particular their gender and age. The evolution of wealth by gender is of relevance, for over the past two centuries there have been massive changes in women's labor force participation, capacity to manage their own affairs, and life expectancy relative to men. The evolution of wealth by age is of relevance because there was a significant increase in adult life expectancy over the twentieth century and because the progressive diffusion of pensions may have changed savings motivations. Moreover, age-wealth profiles also inform us about the motives of wealth accumulation and the economic impact of high wealth concentration.

A first pass at the data considers the gender breakdown of wealth at death. Remarkably, in our micro data the share of women in top estates takes its highest value on the eve of World War I. For instance, the women's share in the top 0.5 percent rose from 35 percent prior to 1850 to 45 percent in 1902, only to fall to 40 percent after World War II. Strikingly, women's share of wealth follows almost exactly the pattern of aggregate inequality. Women were relatively richer when inequality reached its apex in France than at any other time. Moreover, institutional variables seem to have played almost no role in changing the relative wealth of women. Unlike in common law countries, French law, starting with the code civil of 1804, required nearly equal treatment of all children in bequests. Further research will help us determine to what extent women of great wealth were heirs or part of economically very successful couples.

The data also reveal striking changes in the

tration among the living for the twentieth century, due to data limitations: tables broken down by estate brackets and age of decedents are available solely for years 1943-1954 and at the national level (no table broken down by estate brackets and age of decedents has ever been compiled at the département level, except in 1931 for Seine département: see E. S. Danysz, 1934), and the 1994 micro sample is not large enough to allow for a reliable application of the estate multiplier method at the Paris level. Thus, the only wealthof-the-living concentration estimates we provide for the twentieth century are national estimates for 1947 and 1994. 
Table 5-The Age Profile of Wealth at Death in Paris, 1817-1994

(Average estate left by 50-59-year-old $=100$ )

\begin{tabular}{|c|c|c|c|c|c|c|c|c|}
\hline & $\begin{array}{l}20-29 \\
\text { yr-old }\end{array}$ & $\begin{array}{l}30-39 \\
\text { yr-old }\end{array}$ & $\begin{array}{l}40-49 \\
\text { yr-old }\end{array}$ & $\begin{array}{l}50-59 \\
\text { yr-old }\end{array}$ & $\begin{array}{l}60-69 \\
\text { yr-old }\end{array}$ & $\begin{array}{l}70-79 \\
\text { yr-old }\end{array}$ & $\begin{array}{l}80-89 \\
\text { yr-old }\end{array}$ & $\begin{array}{l}90-99 \\
\text { yr-old }\end{array}$ \\
\hline 1817 & 26 & 22 & 28 & 100 & 54 & 59 & 59 & \\
\hline 1827 & 44 & 50 & 53 & 100 & 88 & 87 & 60 & \\
\hline 1837 & 133 & 90 & 107 & 100 & 116 & 123 & 110 & \\
\hline 1847 & 87 & 73 & 102 & 100 & 117 & 204 & 132 & \\
\hline 1857 & 84 & 77 & 101 & 100 & 104 & 109 & 145 & \\
\hline 1867 & 67 & 58 & 136 & 100 & 141 & 125 & 154 & \\
\hline 1877 & 66 & 73 & 63 & 100 & 197 & 260 & 430 & \\
\hline 1887 & 45 & 33 & 63 & 100 & 152 & 233 & 295 & \\
\hline 1902 & 29 & 40 & 80 & 100 & 253 & 272 & 401 & \\
\hline 1947 & 31 & 51 & 73 & 100 & 113 & 105 & 105 & 109 \\
\hline 1994 & & 11 & 45 & 100 & 87 & 93 & 95 & 68 \\
\hline
\end{tabular}

Source: Authors' computations using estate tax returns (see Piketty et al., 2004, Table A1, for detailed sources).

age profile of wealth between 1807 and 1994 (see Table 5). During the nineteenth century, as wealth concentration was increasing, the very rich were getting older and older. At the beginning of the nineteenth century, in the aftermath of the French Revolution, the richest individuals were those in their fifties: they were typically 100 percent richer on average than people in their forties, 25 percent richer than those in their sixties, and 40 percent richer than those in their seventies and eighties. By the 1870s, however, the age-wealth pattern had become strongly monotonic: the richest individuals were the oldest individuals. In 1902, people in their sixties and seventies bequeathed 150 percent more than those in their fifties, and those in their eighties 300 percent more! On the eve of World War I, top wealth holders were old and likely to be retired. This pattern breaks some time during the $1914-1945$ period. ${ }^{33}$ In 1947 as well as in 1994, we are back to a pattern where the richest individuals are those in their fifties. Overall, the period of maximal wealth inequality (1860 1913) also appears to be a period characterized by a very specific age profile of wealth and large concentration of assets among the elderly.

Another way to analyze the changing agewealth relationship is to look at average age by

\footnotetext{
${ }^{33}$ Existing evidence on the age-wealth profile for 1931 (see Danysz, 1934) suggests that the Great Depression and World War II (rather than World War I) played the leading roles in breaking this pattern. This is an issue we plan to investigate in future research.
}

top estate fractile. ${ }^{34}$ In 1817 , average age was virtually the same for the top 10 percent and the top 1 percent of estates (or even slightly declining). The average-age-per-fractile relationship becomes upward sloping during the nineteenth century, and by 1902 those in the top 1 percent were almost six years older than those in the top 10 percent. The relationship is flat in 1947 and downward-sloping in 1994. Finally, one can apply the estate multiplier method (see Section IV above) and analyze how wealth concentration by age group among the living changed over the course of the nineteenth century. The general population in Paris did not become older during the nineteenth century: those aged 60 or older made up about 15 percent of the population in 1817 , and after 1847 about 10 to 11 percent. $^{35}$ The share of total wealth owned by the elderly rose significantly, however, as wealth distribution worsened. The wealth belonging to those aged 60 or more rose from about 25 to 30 percent of the total at the beginning of the nineteenth century to about 40 to 45 percent by the end of the century. The wealth share of those aged 70 or older doubled, from less than 10 percent to about 20 percent. ${ }^{36}$

\footnotetext{
${ }^{34}$ See Piketty et al. (2004, Table 6).

${ }^{35}$ Although life expectancy was increasing, which should have led to large shares of population for older groups, the city was also growing quickly. The large number of immigrants (who were typically in their twenties) increased the relative size of the younger cohorts (see Piketty et al., 2004, Table 7 and Figure 11).

${ }^{36}$ See Piketty et al. (2004, Figure 12).
} 
It is perhaps not surprising that inequality became strongly correlated with age in the 1860s. Those who died at an old age in the 1820 s and 1830s had lived through the difficult years of the French Revolution and the dislocation of the end of the Napoleonic period. Their ability to accumulate wealth had been severely impaired. Furthermore, they were rather less likely to inherit much wealth, since the Revolution wiped out the bond portfolios of their parents through a prolonged period of high inflation. Those who died from the 1860s to the early 1910s did not suffer from the adversities that plagued their forebears. Instead, they enjoyed the fruits of the financial sector expansion that began in the 1850s. After 1947, we seem to have returned to a situation quite like that of 1817. Presumably, the capital damages associated with both world wars and the Great Depression had a strong negative effect on the wealth holdings of older generations. The persistence of a flat age-wealth profile until 1994 is likely to be associated with two factors. First, in societies where income growth is rapid, absolute wealth accumulation is faster by younger cohorts than by older ones because their incomes are higher at every age. This is an important distinction between the nineteenth century and the twentieth century. Furthermore, highly progressive rates of income and estate taxation have probably made it more difficult to accumulate large fortunes, thereby flattening the observed age-wealth profile.

The more interesting (and more difficult) question relates to the possible efficiency impact of high wealth concentration and changing age-wealth profiles. Although our data do not allow us to address efficiency issues in a rigorous way, our results allow us to formulate a number of hypotheses and to shed new light on the ongoing debate on inequality and growth. ${ }^{37}$ From a theoretical viewpoint, whether high wealth concentration can have a negative growth impact depends critically on the existence of credit constraints. With first-best credit

\footnotetext{
${ }^{37}$ Thus far, this literature has concentrated upon crosscountry regressions of inequality on growth, a methodology that raises serious identification problems, especially given the low quality of available international datasets on inequality, which are neither long-run nor homogeneous (see, e.g., Atkinson and Andrea Brandolini, 2001).
}

markets, money flows toward the best entrepreneurs and investment projects, irrespective of the initial distribution. High levels of wealth concentration can be bad from a social justice viewpoint, but they entail no efficiency loss. When credit constraints bind, however, initial wealth matters, and high levels of inequality can hurt growth. Whether the loss is large or small depends on who owns the assets. If the rich are efficient investors (they know which projects to fund, etc.), then wealth concentration may even be useful. If the rich are retired rentiers, however, investing their wealth in low-yield assets (or low-ability inheritors), then high wealth concentration and credit constraints might prevent talented but penniless investors from undertaking efficient projects, thereby entailing negative growth consequences. The data used in this paper are not ideal to address whether credit constraints were important in a country like France at the end of the nineteenth century. Our results suggest, however, that to the extent credit constraints were indeed severe, high wealth concentration did have a negative growth impact. In order to investigate this hypothesis further, one would need to gather more systematic data on investment strategies and asset returns. Preliminary evidence suggests that the rich elderly of the 1860-1913 period did, indeed, hold a disproportionate fraction of their wealth in low-yield assets (such as government bonds). An alternative hypothesis, however, is that steeper age-wealth profiles were the consequence of the growth of financial markets: as their children faced fewer credit constraints, parents decided to hold on to more of their wealth.

\section{Conclusion}

Evidence from wealth at death in Paris and in France over the last two centuries reveals three key patterns. First, wealth concentration has changed dramatically over time. In 1807, the top-1-percent share of wealth (40 percent in France, 50 percent in Paris) was twice as high as it would be in 1994, but substantially less than in 1913 when it peaked above 55 percent in France and 70 percent in Paris. Some of these changes were due to economic phenomena that have long been emphasized as creating inequality, namely industrialization and financial cen- 
tralization. Yet the decline comes largely from adverse shocks, rather than economic convergence. These changes are of such magnitude that they are not sensitive to whether one examines wealth at death in Paris or in France, or whether one examines it directly rather than converting it to wealth of the living by an estate multiplier method.

Our second key result is that there was a significant transition during the nineteenth century from an important role for real estate as a form of wealth to moveable assets as the key form of wealth for the very rich. Similarly, the share of wealth held by aristocrats first rose and then was eclipsed by that of financiers and industrialists in the second half of the nineteenth century. Hence, mobility within this highly unequal society might have been quite high. Yet this conjecture is tempered by our third finding: the wealthy were getting older over time, and older relative to less wealthy decedents. Such aging among the very wealthy would have had negative consequences for growth if financial markets were imperfect. This issue requires further investigation, and we hope it will attract future research.

\section{REFERENCES}

Atkinson, Anthony B. "Top Incomes in the UK over the 20th Century." Journal of the Royal Statistical Society: Series A (Statistics in Society), 2005, 168(2), pp. 325-43.

Atkinson, Anthony B. and Brandolini, Andrea. "Promise and Pitfalls in the Use of 'Secondary' Data-Sets: Income Inequality in OECD Countries as a Case Study." Journal of Economic Literature, 2001, 39(3), pp. 771-99.

Atkinson, Anthony B. and Harrison, Alan J. Distribution of personal wealth in Britain. Cambridge: Cambridge University Press, 1978.

Atkinson, Anthony B. and Piketty, Thomas. Top incomes over the twentieth century: A contrast between European and English speaking countries. Oxford: Oxford University Press (forthcoming).

Banerjee, Abhijit V. and Duflo, Esther. "Inequality and Growth: What Can the Data Say?" Journal of Economic Growth, 2003, 8(3), pp. 267-99.

Bourdieu, Jérome; Postel-Vinay, Gilles and SuwaEisenmann, Akiko. "Pourquoi la richesse ne s'est-elle pas diffusée avec la croissance? Le degré zéro de l'inégalité et son évolution en France: 1800-1940." Histoire et mesure, 2003, 18(1-2), pp. 147-98.

Bourdieu, Jérome; Postel-Vinay, Gilles and SuwaEisenmann, Akiko. "Défense et illustration de l'enquête des 3000 familles: L'exemple de son volet patrimonial." Annales de démographie historique, 2004, 19, pp. 19-57.

Danysz, E. S. "Contribution à l'étude des fortunes privées d'après les déclarations de successions." Bulletin de la statistique générale de France, 1934, XXIV (1), pp. 111-171.

Daumard, Adeline. Les fortunes française au XIXe siècle: Enquête sur la répartition et la composition des capitaux privés à Paris, Lyon, Lille, Bordeaux et Toulouse d'après l'enregistrement des déclarations de succession. Paris: Mouton, 1973.

Gain, André. La restauration et les biens des émigrés. 2 vols. Nancy: Société d'impression typographique, 1929.

Jones, Alice H. American colonial wealth: Documents and methods. 3 vols. New York: Arno Press, 1977.

Kopczuk, Wojciech and Saez, Emmanuel. "Top Wealth Shares in the United States, 19162000: Evidence from Estate Tax Returns." National Tax Journal, 2004, 57(2), pp. 44587.

Kuznets, Simon. "Economic Growth and Income Inequality." American Economic Review, 1955, 45(1), pp. 1-28.

Lampman, Robert J. The share of top wealthholders in national wealth, 1922-1956. Princeton: Princeton University Press, 1962.

Lescure, Michel. Les banques, l'Etat et le marché immobilier en France à l'époque contemporaine, 1820-1940. Paris: Editions l'Ecole des Hautes Etudes en Sciences Sociales, 1982.

Lévy-Leboyer, Maurice and Bourguignon, Francois. L'Economie française au XIXe siècle: Analyse macroéconomique. Paris: Economica, 1985. English translation, Cambridge: Cambridge University Press, 1990.

Lindert, Peter H. "Unequal English Wealth since 1670." Journal of Political Economy, 1986, 94(6), pp. 1127-62.

Lindert, Peter H. "Three Centuries of Inequality in Britain and America," in Anthony B. Atkinson and François Bourguignon, eds., 
Handbook of income distribution. Vol. 1. Amsterdam: Elsevier Science, North-Holland, 2000, pp. 167-216.

Morrisson, Christian. "Historical Perspectives on Income Distribution: The Case of Europe," in Anthony B. Atkinson and Francois Bourguignon, eds., Handbook of income distribution. Vol. 1. Amsterdam: Elsevier Science, North-Holland, 2000, pp. 217-60.

Morrisson, Christian and Snyder, Wayne. "Les inégalités de revenus en France du début du XVIIIème siècle à 1985." Revue économique, 2000, 51(1), pp. 119-54.

Piketty, Thomas. Les hauts revenus en France au XXe siècle-Inégalites et redistributions, 1901-1998. Paris: Grasset, 2001.
Piketty, Thomas. "Income Inequality in France, 1901-1998." Journal of Political Economy, 2003, 111(5), pp. 1004-42.

Piketty, Thomas; Postel-Vinay, Gilles and Rosenthal, Jean-Laurent. "Wealth Concentration in a Developing Economy: Paris and France, 1807-1994." Center for Economic Policy Research, CEPR Discussion Papers: No. 4631, 2004.

Piketty, Thomas and Saez, Emmanuel. "Income Inequality in the United States, 1913-1998." Quarterly Journal of Economics, 2003, 118(1), pp. 1-39.

Soltow, Lee and van Zanden, Jan L. Income and wealth inequality in the Netherlands 16th-20th century. Amsterdam: Het Spinhuis, 1998. 